\title{
Earning Quality Effect on Stock Returns: GCG and CSR Mechanism
}

\author{
Diah Permata Sari ${ }^{*}$, Hari Setiyawati ${ }^{2}$ \\ 1,2Department of Accounting, Universitas Mercu Buana, Indonesia \\ *Corresponding Author: diahpermatasari854@gmail.com
}

\begin{abstract}
This study explores the effect of corporate governance mechanisms and disclosure of corporate social responsibility on earnings quality and the effect on stock returns. The mining sector research analysis is indexed on the Indonesia Stock Exchange for the period 2014 to 2018. The research method used is causal research, with the analysis method used is multiple linear regression. The sampling technique used purposive sampling. The results showed that Managerial Ownership, Institutional Ownership, Independent Commissioners, and CSR disclosure did not affect earnings quality, while the Audit Committee and Stock Returns significantly affected earnings quality. This study's findings contribute to financial performance, particularly the relationship between corporate governance, CSR disclosure, and earnings quality. These findings can be a consideration for investors in making policies on their investments.
\end{abstract}

Keywords: CSR Disclosure; Earnings Quality; GCG Mechanism; Stock Return.

\section{INTRODUCTION}

The company's earnings information does not imply that the earnings are of high quality. Earnings are considered high-quality as financial statement clients can use them to make the right choices and satisfy the qualitative requirements for accurate and trustworthy financial reports (Warianto \& Rusiti, 2016). The quality of earnings is one of the financial success metrics that readers of financial statements used to make economic decisions. There are two types of parties that need financial reports: internal business parties such as administrators, managers, and external parties such as investors, creditors, and the government (Listyaningsih, 2020).

There are also issues in Indonesia with firms publishing false financial results, one of which is PT. Timah Tbk, a mining firm that perpetrated a public lie in 2015 by issuing a financial report for the first semester of 2015, stated that efficiency and strategy had good financial success. However, the actual financial statements reported net profit for the first semester of 2015 was a deficit of IDR. 59 billion. The Tin Employees Association (IKT, an Indonesian abbreviation) has called for the board of commissioners and directors to resign immediately due to this situation. The new board of directors is expected to improve its performance (mining.co.id, 2016). 
As a result of the phenomena mentioned earlier, various factors, including the Good Corporate Governance Mechanism, will affect earnings quality. According to Nasrum (2018), the corporate governance mechanism is a well-defined enforcement law, procedure, and relationship between the decision-maker and the decision supervisor. In Agency Theory, Jensen and Meckling (1976) define a situation in which management or agents appointed by shareholders (principal) on their behalf are responsible for generating profitability now and then. According to this theory, agents are more likely to use company resources for their gain than for the benefit of the company's owners. In this analysis, Agency Theory is viewed as a theoretical approach consistent with the GCG process. Management (agent) performs its duties under the contract with the principal to serve the principal's interests. In a company, the principal and the control agent's division of ownership appears to establish agency disputes between the principal and the agent. The contract is signed because the agent does not always behave in the principal's best interests, resulting in agency costs (Nuryana \& Surjandari, 2019). The GCG mechanism is based on Agency Theory, which is used to resolve agency issues between the owner (principal) and the management (agent). The failure to enforce the GCG mechanism is associated with a lack of accountability in the company's management, which leads to the loss of general control and the involvement of the controlling shareholder in the company's management. It can result in a conflict of interest that explicitly violates corporate governance standards, lowering the quality of the company's earnings (Listyaningsih, 2020). The Corporate Governance System includes Managerial Ownership, Institutional Ownership, the Independent Board of Commissioners, and the Audit Committee (Nuryana \& Surjandari, 2019).

The relation between the GCG mechanism and Earning Quality proxied by Managerial Ownership, Institutional Ownership, the Independent Board of Commissioners, and the Audit Committee is based on a previous Polimpung study (2020). According to the report, managerial ownership has an impact on Earning Quality. Arniati et al. (2019) conducted the same research and concluded that the Independent Board of Commissioners impacted Earning Quality. According to Hamdan (2020) and Mahdi et al. (2020). The Audit Committee has a substantial impact on the company's earnings quality.

Contrary to the previous study, the findings of Listyaningsih (2020) show that institutional and managerial ownership has no impact on quality earnings. Similarly, according to the findings of Handoko (2020), managerial ownership and the audit committee have no impact on earnings quality. According to Arniati et al. (2019), the independent board of commissioners does not affect earnings quality.

Other variables that may influence earnings quality, such as CSR disclosure, are being investigated in this study. Disclosure of Corporate Social Responsibility is a disclosure of information aimed at interested parties. Social disclosures made by companies are generally voluntary, unaudited, and unregulated (Setiyawati \& Basar, 2017). It concerns Government Regulation No 47, 2012, on Corporate Environmental Responsibility Implementation. Social and environmental responsibility practices and the dissemination of information are the responsibilities of the entire company under this government regulation (IAI, 2015). The public disclosure of a company's CSR activities serves as a barometer for financial reporting transparency and demonstrates its accountability to stakeholders. However, the company's social reporting is simply 
a management strategy for manipulating earnings efficiency. It is confirmed by previous research by Park \& Ha (2020), Suwarno et al. (2020), Rezaee et al. (2019) and Jouber (2019) and (Bagus and Djaddang (2018), indicating that companies with good CSR disclosure have higher earnings efficiency.

In contrast to the findings of a study conducted by (Hutasoit et al., 2020), CSR disclosure has no impact on earnings quality. GRI G-4 was used to test CSR disclosure in this report. The Global Reporting Initiative (GRI) is used to build and offer reporting benefits to company stakeholders through reporting and standardized disclosures that signify corporate social responsibility. These guidelines are intended for companies of all sizes, sectors, and locations. It also serves as a global resource for all parties interested in identifying environmental, social, economic, and organizational governance, efficiency, and impacts (GRI G-4, 2013: 5)

Since leverage is assumed to influence the efficiency of a company's earnings, it was used as a control variable in this study. According to Hartono (2017), if a company's assets are funded primarily by debt rather than its capital, its leverage will be higher, and the quality of its earnings will be more inferior. The source of company funds may come from its resources or loan when running a company. Sulistyanto (2014) explains that debt or leverage is an economical cost made by a corporation in the future, in the form of the supply of goods or services resulting from past transactions or events. It is confirmed by earlier research (Febriani et al., 2020), which notes that leveraging has a negative impact on the quality of the earnings. The findings of research carried out by Indriani (2020) are different and show that leverage impacts earnings efficiency.

The size of the firm is another control variable used in the analysis other than leverage. Brigham (2019) defines that "Firm Size is the size of a company that is shown or valued by total assets, total sales, generated profits, tax expense and others". One of the factors that determine the quality of earnings is the size of the firm. Firm size is assumed to impact earnings quality. Since the bigger the company size, the easier it would be to receive funding sources and the higher the quality of earnings (Putra, 2020). Compared to research conducted by (Safitri et al., 2020), which claims that firm size has no impact on earnings quality, previous research conducted by (Putra 2020) claims that firm size affects earnings quality.

Investors rely on earnings data to make decisions about whether or not to invest in a company. If a company's earnings is high, investors' returns are likely to be high as well, and vice versa (Yuliza, 2018). It can be deduced from this explanation that earnings quality information affects stock returns. If investors assume they will receive security and a guaranteed return, they are more likely to invest. The higher the rate of return, the greater the company's profitability and earnings quality. It is confirmed by previous research (Yuliza, 2018; Simorangkir, 2019), which found that earrings' quality affects stock returns. However, according to a different study (Damanik, 2019), earnings efficiency does not affect stock returns.

Based on the explanations mentioned earlier, hypotheses, and previous studies, This study aims to learn more about the effects of the GCG process, CSR disclosure, earnings quality, and its effect on stock returns using Leverage and Firm Size as control variables. The research was carried out in the Indonesia Stock Exchange (IDX) mining sector during 2014 to 2018. The mining industry was selected for the study 
because mining companies are one of the nation's economic pillars, and their inclusion contributes to state revenue for social welfare. According to data released by the Indonesian Mining Association (IMA) in 2019, the mining industry contributed the most to state revenue, with IDR 37 trillion in 2017 and IDR 46.6 trillion in 2018.

This study is intended to provide theoretical contributions to academics and other interested parties, allowing them to generate research ideas for future studies. Meanwhile, in terms of practical contribution, it is expected to advise the corporation on developing the GCG mechanism and CSR disclosure to improve earnings efficiency and stock returns. In terms of policy contribution, it is expected to provide data to inform companies in developing corporate governance strategies that will allow them to achieve successful financial reporting.

\section{HYPOTHESIS DEVELOPMENT}

\section{Managerial Ownership's Effect on Earnings Quality}

Under Law No. 40 of 2007 on Limited Liability Companies states, Commissioners and directors must disclose the number of shares they hold in their companies and other companies to the corporation if they own shares in both (Hapsoro \& Shufia, 2018). As Jensen and Meckling (1976) stated, Managers and shareholders' interests can be matched if managers own a greater share of the business. If a manager is also a shareholder, it is assumed that this would reconcile differences in preferences between outside shareholders and management, reducing agency conflicts ( (Nanang \& Tanusdjaja, 2019). Increasing managerial ownership will minimize earnings manipulation, allowing reported earnings to represent the company's actual economic situation better. Furthermore, pressure from the stock market encourages businesses with low managerial ownership to use accounting practices to inflate estimated profits, causing them to misrepresent the company's economic situation (Indrawati et al., 2010). According to previous research (Polimpung, 2020; Ismail, 2018; Barkadehi \& Mirbargkar, 2017). Managerial ownership has an impact on improving earnings quality. Contrary to previous research findings by (Listyaningsih 2020) and (Handoko et al., 2020), Managerial ownership has no impact on earnings efficiency. The following hypothesis is formulated based on the analysis:

\section{$\mathrm{H}_{1}$ : Management ownership's has an impact on the quality of earnings}

\section{The institutional ownership's Effect on Earnings Quality}

Institutional ownership plays a vital role in corporate governance in reducing agencies' cost (Mehdi et al., 2017). According to Bushee (1998), institutional ownership through an intense level of supervision can reduce managers' incentives who only think about personal interests. Institutional ownership can reduce discretionary expenditure in financial reports, improving reported earnings (Indrawati et al., 2010). According to Irawati and Sudman (2016), institutional ownership supervises the corporation while the firm manager controls it. Supervision of the company will increase along with the increase in institutional ownership and management. It has to do with institutional investors' position in overseeing company results, preventing conflicts of interest from minority shareholders, and limiting earnings management actions (Nuryana \& Surjandari, 2019). Research conducted by Barkadehi and Mirbargkar (2017) has shown that institutional ownership positively impacts earnings quality. It differs from the research results carried out by (Handoko et al., 2020) and (Arniati et al., 2019), which state that institutional ownership has no impact on earnings quality. According to the results, 
the hypothesis will go as follows:

$\mathrm{H}_{2}$ : Institutional ownership has an impact on the quality of earnings

\section{The Independent Commissioners' Board Effect on Earnings Quality}

Beasley's (1996) study explores the relationship between the proportion of commissioners on board and fraudulent financial reporting. When they conduct audit comparisons between businesses that have committed fraud and those that have not, they find that companies that commit fraud have a substantially lower number of external commissioners than those that do not. Another attribute of earnings knowledge is the composition of the board (Nanang \& Tanusdjaja, 2019). The Commissioners' Board's supervision role is influenced by the size of the Commissioners' Board (Indrawati et al., 2010). The independent board of commissioners' role in carrying out the company's operational, supervisory function includes making a significant contribution to the results of quality report preparation and avoiding earnings management to improve the quality of the company's earnings (Arisanti, 2020). The findings of the research conducted by (Mahdi et al., 2020) indicate that independent boards of commissioners impact the quality of earnings. In comparison to the findings of the research conducted by Arniati et al., 2019, the independent board of commissioners has no impact on earnings quality. Based on this study, the suggested hypothesis is as follows:

\section{$\mathrm{H}_{3}$ : The Independent Commissioners' Board has an impact on the quality of earning}

\section{The Audit Committee's Effect on Earnings Quality}

The management performance can be monitored and supervised with a company audit committee, whether it meets company standards and targets (Nanang \& Tanusdjaja, 2019). The greater the size of the audit committee inside the corporation within the optimum limits, the greater the quality of earnings expressed in the financial statements of earnings (Nuryana \& Surjandari, 2019). The audit committee serves as a conduit between the external auditor and the corporation and between the commissioners' supervisory role and the internal auditor. The knowledge quality of earnings is improved by increased independence and audit committee operations (Indrawati et al., 2010). The impact of increasing the independence of the audit committee will decrease if the audit committee is involved. The audit committee members' independence is considered a mechanism for controlling the financial reporting process (Nuryana \& Surjandari, 2019). Therefore, indicators of independence may be used to determine earnings quality. The results of research by Handoko \& Arbi (2020), Mahdi et al. (2020) and Hamdan (2020) indicate an impact on the earnings quality from the audit committee. It differs from the findings of previous research carried out by Handoko et al. (2020), which reported that the audit committee had no impact on earnings quality. Based on the study, the hypothesis proposed is as follows:

$\mathrm{H}_{4}$ : The Audit Committee's has an impact on the quality of earning

\section{Earnings}

The Corporate Social Responsibility (CSR) Disclosure Effect on the Quality of

In the annual report of the company, Hutasoit et al. (2020) argue that CSR disclosure is one of the company's business strategies to increase the quality of its earnings, where companies that perform better with CSR are more likely to report the quality of earnings expected by investors than other companies. CSR operation disclosure 
will serve as a benchmark for financial reporting transparency and corporate accountability to stakeholders. High-income management leads to low-profit quality, while low-income management leads to high revenue quality. One reason for management to do social reporting is that CSR activities will provide a shield for management to exploit revenue (Muttakin el at, 2015). Previous research on the relationship between CSR disclosure and earnings quality (Park \& Ha, 2020), (Suwarno et al., 2020), (Rezaee et al., 2019), (Jouber, 2019) and (Bagus \& Djaddang, 2018) has shown that companies with good CSR disclosure will likely have better earnings quality. It contrasts with the findings of a study by Hutasoit et al. (Hutasoit et al., 2020), which found that CSR disclosure has no impact on earnings quality. The following hypothesis is suggested based on the analysis:

$\mathrm{H}_{5}$ : The CSR disclosure has an impacts on the quality of earnings

\section{The impact earnings quality on stock returns}

The benefit/return relationship is based on the premise that earnings is beneficial to investors. Several previous studies that have tested this empirically have accepted the premise that earnings have usefulness. The pioneers who studied the relationship between information quality and earnings figures were Ball, R. J., Brown (1968), and Beaver (1968). The reported earnings figures would be helpful if the market responds to the announcement of annual earnings reporting, according to Ball, R. J., and Brown (1968). They show a connection between changes in annual earnings and changes in stock prices. According to Ray \& Philip (1968), if the market responds to the announcement of annual earnings reporting, the published earnings figures would be helpful. They show a connection between changes in annual earnings and changes in stock prices. The findings of past studies (Simorangkir, 2019; Damanik et al., 2019; Yuliza, 2018) indicate that returns on company stocks affect earnings quality. It differs from Nurmasari (2018) study findings, which found that stock returns have no impact on earnings quality. Based on the data, the hypothesis is:

$\mathrm{H}_{6}$ : The Quality earnings has an impact on stock return

As shown in Figure 1, the analysis uses the framework above to describe the relationship between the relationships and the research objectives.

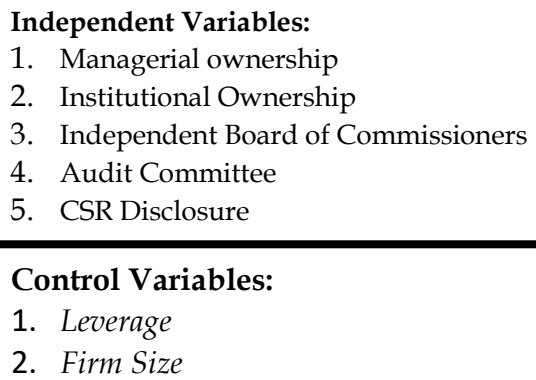

Figure 1. The Framework between the relationships and the research objectives 


\section{METHOD, DATA, AND ANALYSIS}

\section{Design of research, sample and population}

The method of study is quantitative research. It was a confirmatory analysis to confirm the hypothesis about the independent variable's impact on the dependent variable. The population consists of mining companies listed on the Indonesian Stock Exchange for the period 2014-2018. There were 49 companies in the sample population. Purposive sampling is used in this procedure, with the following criteria: (a) businesses that have published financial reports regularly from 2014 to 2018 (b) organizations that have released CSR reports for the years 2014-2018. The mining companies sampled in this study were 30 and were selected based on these criteria. In this report, the techniques for statistical analysis used version 11 of E-Views, as shown in Table 1.

Table 1. List of Research Variables Operational definition

\begin{tabular}{|c|c|c|c|c|}
\hline No & Variable & Dimension & Indicator & $\begin{array}{c}\text { Measurem } \\
\text { ent Scale }\end{array}$ \\
\hline \multirow{4}{*}{1} & \multirow{2}{*}{$\begin{array}{l}\text { Mekanisme } \\
\text { Good Corporate } \\
\text { Governance }\end{array}$} & Managerial ownership & $\begin{array}{l}\text { Managerial ownership }= \\
\frac{\text { Numberof ManagerialShares }}{\text { Numberof Sharesoutstanding }} \times 100 \%\end{array}$ & Ratio \\
\hline & & $\begin{array}{l}\text { Institutional } \\
\text { Ownership }\end{array}$ & $\begin{array}{l}\text { NumberofSharesOutstanding } \\
\text { Institutional Ownership }= \\
\frac{\text { NumberofInstitutionalShares }}{\text { NumberofSharesoutstanding }} \times 100 \%\end{array}$ & Ratio \\
\hline & $\begin{array}{l}\text { (Nuryana \& } \\
\text { Surjandari, } \\
\text { 2019) }\end{array}$ & $\begin{array}{l}\text { Independent Board of } \\
\text { Commissioners }\end{array}$ & $\begin{array}{l}\text { Independent Board of } \\
\text { Commissioners }= \\
\text { इCommissioners }\end{array}$ & Ratio \\
\hline & & Komite Audit & $\begin{array}{l}\text { AAllCommissioners } \\
\text { Audit Committee }=\Sigma \text { Audit } \\
\text { Committee }\end{array}$ & Ratio \\
\hline 2 & CSR disclosure & GRI 4 & $\mathrm{CSDIj}=\frac{\text { Numberofindicatorsdisclosed }}{91}$ & Ratio \\
\hline 3 & $\begin{array}{l}\text { Leverage } \\
\text { (brigham, 2020) }\end{array}$ & Debt Equity Ratio & $\mathrm{DER}=\frac{\text { TotalAmountofdebt }}{\text { TotalEquity }} \times 100 \%$ & Ratio \\
\hline 4 & $\begin{array}{l}\text { Firm Size } \\
\text { ( brigham, 2020) }\end{array}$ & Total Assets & Size $=$ Ln Total Aset & Ratio \\
\hline 5 & $\begin{array}{l}\text { Earnngs Quality } \\
\text { (James Ohlson, } \\
\text { 1995) }\end{array}$ & Value Relevance & $\begin{array}{l}\text { Pit }=\beta o+\beta \text { EPSit }+\beta_{2} \text { BVSit }+ \text { cit. } \\
\text { Note: } \\
\text { Pit: Stock Price for company } i \text { at } \\
\text { the end of the year } \\
\text { EPSit : Earning Per Share of } \\
\text { company i in period } t \\
\text { BVSit : Book Value Per Share of } \\
\text { company I in period } t\end{array}$ & Ratio \\
\hline 6 & $\begin{array}{l}\text { Stock returns } \\
\text { (Eugene F. } \\
\text { brigham, 2020) }\end{array}$ & Capital Gain & $\begin{array}{l}\text { Stock returns }=\frac{P t-(P t-1)}{P t-1} \\
\text { Note: } \\
\mathrm{Pt}: \text { closing price of company I } \\
\text { shares in period } \mathrm{t} \\
\mathrm{P}_{\mathrm{t}-1} \text { : closing price of the shares of } \\
\text { company I in the previous } \\
\text { period }\end{array}$ & Ratio \\
\hline
\end{tabular}




\section{RESULT}

The maximum, minimum, standard deviation, and total observations for all variables in this analysis are shown in Table 2.

Table 2. Descriptive Statistics

\begin{tabular}{lccccccccc}
\hline & KM & KI & DKI & KA & CSR & SIZE & LEV & VR & RS \\
\hline Mean & 7.429 .0 & 6.390 .2 & 3.873 .4 & 3.133 .3 & 0.2007 & 2.942 .1 & 5.616 .4 & 1.630 .1 & 0.26820 \\
& 65 & 30 & 39 & 33 & 33 & 03 & 33 & 87 & 1 \\
Median & 0.00840 & 6.510 .0 & 3.333 .3 & 3.000 .0 & 0.1813 & 2.933 .9 & 0.77381 & 7.146 .0 & 0.00000 \\
& 0 & 00 & 33 & 00 & 19 & 10 & 4 & 12 & 0 \\
Maximum & 9.561 .0 & 9.739 .0 & 7.500 .0 & 5.000 .0 & 0.5494 & 3.225 .8 & 6.573 .3 & 15904.0 & 8.444 .4 \\
& 00 & 00 & 00 & 00 & 50 & 41 & 02 & 8 & 00 \\
Minimum & 0.00000 & 0.00000 & 2.000 .0 & 2.000 .0 & 0.0439 & 2.662 .3 & 0.04245 & 4.656 .6 & - \\
& 0 & 0 & 00 & 00 & 56 & 89 & 1 & 56 & 0.90420 \\
& & & & & & & & & 0 \\
Std.Dev. & 1.748 .6 & 1.919 .9 & 9.834 .4 & 0.47298 & 0.1117 & 1.318 .6 & 5.358 .6 & 2.879 .0 & 1.058 .0 \\
& 18 & 57 & 97 & 4 & 16 & 38 & 68 & 07 & 99 \\
Observati & 150 & 150 & 150 & 150 & 150 & 150 & 150 & 150 & 150 \\
ons & & & & & & & & & \\
\hline
\end{tabular}

Source: Processed data comes from the IDX (http://www.idx.co.id) 2014-2015 using the E-Views statistical technique version 11 .

Based on Table 2, the minimum value of Managerial Ownership (KM) is held by 73 of the 150 observations at 0 percent for the period 2014-2018, while the maximum value of 95.6 percent implies the greatest value of $\mathrm{KM}$. The standard deviation exceeds the average value (mean). It shows that, on average, managerial share ownership in 30 firms has had a reasonably strong percentage data distribution over the last five years. Institutional Ownership (KI) has a minimum value of $0 \%$, indicating that companies in this sample do not have institutional ownership. Simultaneously, the 97,39\% maximum value shows the institutional ownership of a corporation that hits $97,39 \%$. The average (mean) value is larger than the standard deviation, suggesting a relatively good data distribution percentage over the past five years of institutional shareholding in 30 firms. The Independent Commissioner (DKI) has a minimum value of $20 \%$, which means that there are about $20 \%$ of DKI in the company and a maximum value of $75 \%$.

The standard deviation is lower than the average value (mean). It indicates that the distribution of independent commissioners in 30 companies has been poor on average over the last five years. It demonstrates that the number of independent commissioners is distributed differently in each corporation. The Audit Committee (KA) minimum value of 2 represents two audit committees in the company, while the maximum value of 5 represents the presence of five audit committees. The average value (mean) is higher than the standard deviation. It shows that the average number of audit committees in 30 companies has been adequately good over the last five years. CSR disclosure has a minimum value of 0.043956 , meaning that the lowest CSR disclosure is about $4 \%$, and the highest value of 0.549451 , or $55 \%$. The average value (mean) exceeds the standard deviation, suggesting that the average of CSR disclosure in 30 companies over the last five 
years was quite responsible for their social activities. The lowest company's overall asset value in this study is $266,238,917$, as shown by the minimum Firm Size value of $266,238,917$. the maximum value is $3,225,841,055$. The average (mean) value is greater than the standard deviation, which indicates that the average firm size in 30 companies over the last five years is satisfactory. The lowest level of the company's leverage ratio is 0.042 , as shown by the minimum Leverage value of 0.042 . the maximum leverage value is 6.58. The average value (mean) exceeds the standard deviation, suggesting that the average Firm Size in 30 companies has been relatively good over the last five years. The minimum value of profit Quality (VR) is 4,656,656,346, meaning the earning value per share and the book value per share is $4,656,656,346$, while the maximum value is 15904,08 .

The average value (mean) is lower than the standard deviation suggesting that, on average, the quality of earnings information in 30 companies has not been good in the last five years. The minimum value of the stock return is-0.904202, meaning that the return rate on the shares of the company in this analysis does not result in a reduced return. The maximum value is 8.4444 . The average value (mean) is smaller than the standard deviation indicating that the average over the last five years of stock returns in 30 companies is not good. It shows that the returns on research stocks appear to decline year after year. The Stock Return minimum value of -0.904202 shows that the return rate on the company's shares in this analysis does not offer a decreased return. The average value (mean) is less than the standard deviation for the maximum value of 8.44444. It shows that the average stock return in the 30 companies over the last five years has been low. This research shows that stock returns tend to decrease from year to year.

Statistical techniques in data analysis with multiple regression methods use EViews version 11 software. In this study, two regressions were performed: the first with the dependent variable of earnings quality and the second with the dependent variable of stock returns. Table 3 shows the results of the panel data regression model estimation test and model selection.

Table 3. Model estimate outcomes and selection of regression models.

\begin{tabular}{|c|c|c|c|c|}
\hline Type/Model & Common Effect & Fixed Effect & Random Effect & Result \\
\hline \multicolumn{5}{|c|}{ Earnings Quality of Dependent Variable } \\
\hline Chow & $\sqrt{ }$ & $\sqrt{ }$ & & Fixed Effect \\
\hline Hausman & & $\sqrt{ }$ & $\sqrt{ }$ & Random Effect \\
\hline Lagrange Multiplier & $\sqrt{ }$ & & $\sqrt{ }$ & Random Effect \\
\hline Selected Model & & & & Random Effect \\
\hline \multicolumn{5}{|c|}{ Stock Returns of Dependent Variable } \\
\hline Chow & $\sqrt{ }$ & $\sqrt{ }$ & & Common Effect \\
\hline Hausman & & $\sqrt{ }$ & $\sqrt{ }$ & Random Effect \\
\hline Lagrange Multiplier & $\sqrt{ }$ & & $\sqrt{ }$ & Common Effect \\
\hline Selected model & & & & Common Effect \\
\hline
\end{tabular}

The Random Effect Model was used as the Dependent Variable Earning Quality model for the First Regression. Since the Random Effect Model uses the Generalized Least Square (GLS) method to estimate the model, there is no need to test classical assumptions (Surjandari \& Wati, 2020). As for the dependent variable, Stock Return, the selected model is the Common Effect Model. Since the Common Effect model is estimated using the Ordinary Least Square (OLS) method, it helps verify the classical assumptions. The 
Multicollinearity Test and the Heteroscedaticity Test are two classic assumption tests for the Common Effect Model (Surjandari \& Wati, 2020). The autocorrelation test typically collides with data that is distinguished by time series for the autocorrelation test. Furthermore, there is no feature when e-views use panel data (Ghozali \& Ratmono, 2017).

\section{Multicollinearity Test}

Table 4. Multicolonierity Test

\begin{tabular}{lccccccc}
\hline & KM & KI & DKI & KA & CSR & SIZE & LEV \\
\hline KM & 1.000000 & -0.646014 & -0.646014 & -0.022973 & -0.162938 & 0.043422 & -0.030464 \\
KI & -0.646014 & 1.0000000 & 0.015660 & -0.045175 & -0.017740 & -0.103746 & -0.002574 \\
DKI & -0.027189 & 0.015660 & 1.0000000 & -0.230059 & -0.241353 & -0.117139 & -0.042093 \\
KA & -0.022973 & -0.045175 & -0.230059 & 1.000000 & 0.467113 & 0.277338 & 0.148830 \\
CSR & -0.162938 & -0.017740 & -0.241353 & 0.467113 & 1.000000 & 0.360814 & 0.163584 \\
SIZE & 0.043422 & -0.103746 & -0.042093 & 0.277338 & 0.360814 & 1.0000000 & 0.106829 \\
LEV & -0.030464 & -0.002574 & -0.042093 & 0.148830 & 0.163584 & 0.106829 & 1.000000 \\
\hline
\end{tabular}

Table 4 illustrates this point. The coefficient of correlation between the independent variables is $<0.80$, so it can be inferred that there is no multicollinearity.

\section{Heteroscedasticity Test}

Based on Table 3, it can be inferred that the first regression of the Dependent Variable Earning Quality model chosen is the Random Effect Model. Therefore, a Classical Assumption Test is not required (Surjandari \& Wati, 2020). In the meantime, the Common Effect Model has been chosen for the second regression of Dependent Variable Stock Return. Moreover, the assumption test required is the heteroscedasticity test. One way to assess heteroscedasticity is to emphasize the Common Effect Estimate Model. The Unweighted Common Effect model is then compared to the Weighted Common Effect model (Surjandari \& Wati, 2020). The Unweighted Model and the Weighted Common Effect Model are compared in Table 5.

Table 5 contrasts the Unweighted Model with the Common Weighted Impact Model.

\begin{tabular}{lcc}
\hline \multicolumn{1}{c}{ Parameter } & Unweighted & Weighted \\
\hline t Statistic Probability & 0,1083 & 0,0094 \\
R-Squared & 0,035425 & 0,090002 \\
F Statistic Probability & 0,108293 & 0,009407 \\
\hline
\end{tabular}

Table 5 compares the Unweighted and Weighted Common Effect Models with the dependent variable Stock Return based on the values of three predictor parameters: $t, R-$ Squared, and F Statistic Probability. The Unweighted value is greater than the Weighted value. Thus one can infer that the Common Effect Model Weighted is a better model than the Common Effect Model Unweighted. 


\section{HYPOTHESIS}

The panel data regression model of choice for first return dependent variable income output derived from the data processing results The Random Effect Model is the suitable model. As for the Second Regression for Dependent Variables, Stock Return, the appropriate model is the Weighted Common Effect Model. Table 6 displays the Hypothesis of a Random Effect Model with Earnings Quality as the Dependent Variable and a Weighted Common Effect Model with Stock Returns as the Dependent Variable.

Table 6. Hypothesis - Random Effect Model - Profit Quality Variable and Weighted Common Effect - Dependent Variable Stock Return

\begin{tabular}{|c|c|c|c|c|c|}
\hline \multicolumn{6}{|c|}{ Random Effect Model - Dependent Variable Earnings Quality } \\
\hline \multirow{2}{*}{ Hypotheses } & \multirow{2}{*}{$\begin{array}{c}\text { Independent } \\
\text { Variables }\end{array}$} & \multicolumn{3}{|c|}{ Random Effect Model } & \multirow[t]{2}{*}{ Result } \\
\hline & & $\beta$ & $t$-Statistic & $P$-value & \\
\hline $\begin{array}{l}\text { Managerial Ownership's } \\
\text { Effect on Earnings } \\
\text { Quality }\end{array}$ & $\begin{array}{l}\text { Managerial } \\
\text { ownership }\end{array}$ & 0,026428 & 0,450987 & 0,6534 & Rejected \\
\hline $\begin{array}{l}\text { Institutional } \\
\text { Ownership's Effect on } \\
\text { Earnings Quality }\end{array}$ & $\begin{array}{l}\text { Institutional } \\
\text { Ownership }\end{array}$ & $-0,776052$ & $-1,876073$ & 0,0649 & Rejected \\
\hline $\begin{array}{l}\text { The Independent Board } \\
\text { of Commissioners' Effect } \\
\text { on Earnings Quality }\end{array}$ & $\begin{array}{l}\text { Independent Board } \\
\text { of Commissioners }\end{array}$ & $-0,451527$ & $-1,079568$ & 0,2841 & Rejected \\
\hline $\begin{array}{l}\text { The Audit Committee's } \\
\text { Effect on Earnings } \\
\text { Quality }\end{array}$ & Audit Committee & 2,327488 & 2,460371 & $0,0164^{* * *}$ & Accepted \\
\hline $\begin{array}{l}\text { CSR's effect on earnings } \\
\text { quality }\end{array}$ & CSR disclosure & $-0,384276$ & $-1,111504$ & 0,2703 & Rejected \\
\hline Control Variable & Firm Size & 14,66652 & 3,657476 & 0,0005 & \\
\hline & Leverage & $-0,689881$ & $-4,648554$ & 0,0000 & \\
\hline \multicolumn{6}{|c|}{ Weighted Statistics } \\
\hline \multirow[t]{4}{*}{ Statistical Model } & R-Squared & & 0,467720 & & \\
\hline & $\begin{array}{l}\text { Adjusted R- } \\
\text { Squared } \\
\text { Prob(F-statistic) }\end{array}$ & & $\begin{array}{l}0,412926 \\
0,000000\end{array}$ & & \\
\hline & Unweighted Sta & istics & & & \\
\hline & R-Squared & & 0,529062 & & \\
\hline \multicolumn{6}{|c|}{ Weighted Common Effect Model - Variable Dependent Return Saham } \\
\hline \multirow[t]{2}{*}{ Hypotheses } & $\begin{array}{l}\text { Independent } \\
\text { Variables }\end{array}$ & Weighte & $\begin{array}{l}\text { Common E } \\
\quad \text { Results }\end{array}$ & fect Model & \\
\hline & & $\beta$ & $t$-Statistic & $P$-value & \\
\hline $\begin{array}{l}\text { Effect on stock returns } \\
\text { of earnings quality }\end{array}$ & Quality of Earnings & 0,203552 & 0,0094 & $0,0094^{* * *}$ & Accepted \\
\hline \multirow[t]{2}{*}{ Statistical Model } & R-Squared & 0,090002 & & & \\
\hline & $\begin{array}{l}\text { Adjusted } \quad \text { R- } \\
\text { Squared } \\
\text { Prob (F-statistic) }\end{array}$ & & $\begin{array}{l}0,077363 \\
0,009407\end{array}$ & & \\
\hline
\end{tabular}


The panel data regression Random Effect Model's outcome with dependent variable Earnings Quality-Adjusted R-Square on Weighted Statistics is 0.412926 . It can be interpreted that the independent variables used in this model are capable of explaining the dependent variable by $41.29 \%$, and variables outside this model influence the remaining $58.71 \%$.

The better R-Squared value in Unweighted Statistics is 0.529062 or $53 \%$, showing that the impact of all independent variables on earning efficiency is very high since the score is $>50 \%$. The Adjusted R-Square value of 0.077363 is found in the Weighted Common Effect Model panel data's regression results with the dependent variable Stock Return. It indicates that the independent variable of earnings quality has a $7.7 \%$ effect on stock returns, while factors outside the model determine the remaining $92.3 \%$ The RSquared value obtained is 0.090002 or $9 \%$, suggesting that the earnings efficiency indicator has a poor effect since it is less than $50 \%$ of the time.

Earnings Quality shows the importance of Prob (F-statistic) $0.00000<0.05$, It can be deduced that the suitability of the Random Effect Model regression model used has a simultaneous impact on KM, KI, DKI, KA, and CSR on Earnings Quality. The regression results from the data panel of the dependent variable Stock Return has a significant value in the Weighted Common Effect Model of Prob (F-Statistics) $0.009407<0.05$, It can be interpreted that the suitability of the Common Effect Regression Model influences the relationship between Earning Efficiency and Stock Returns.

\section{DISCUSSION}

The t-test regression hypothesis tests (H1) showed that the managerial ownership of earnings quality has a significant p-value of 0.6534 , greater than $a=0.05$. It can be inferred that managerial ownership does not impact earnings quality. It rejects the $\mathrm{H} 2$ hypothesis. This study's findings show empirically that management ownership does not improve the efficiency of corporate earnings as certain firms have relatively limited management ownership, which makes management less capable of influencing decisionmaking in operating businesses. The consequence is that the small percentage of managerial ownership as the business owner has little bearing on the financial accounts reflecting the quality of the earnings. Data from this study indicate that for the period 2018-2018, the amount of management ownership in the mining sector listed on the Indonesian stock exchange is meager. There are 73 observations out of 150 observations, indicating the company's managerial ownership is $0 \%$. Moreover, based on research results, the managerial ownership structure has family relationships (relations) and a solid and strategic role in the business structure. It can lead to earnings management opportunities that increase corporate profits' profitability so that earnings quality does not represent the actual situation (Nanang \& Tanusdjaja, H. (2019).

It can contribute to earnings management opportunities by improving the quality of earnings that do not accurately represent the actual situation (Nanang \& Tanusdjaja, H. (2019). According to Theory Agency (Jensen \& Meckling, 1976), the higher management's shareholding, the greater the management's propensity to maximize resource usage. The findings of this analysis are consistent with previous studies (Listyaningsih, 2020). Managerial ownership has no impact on earnings quality, according to Nanang \& Tanusdjaja (2019), Handoko \& Horison (2020). It refers to the percentage of managerial 
ownership that holds little or no stock in the company, allowing RUPS to control its policies and regulations on behalf of all shareholders. The research is not consistent with earlier research (Handoko \& Arbi, 2020), (Polimpung, 2020) and (Barkadehi \& Mirbargkar, 2017) in which managerial ownership can increase earnings quality.

The regression results of the t-test in this analysis suggest that institutional ownership of earnings quality has a p-value of 0.0649 greater than $\alpha=0.05$. It can be inferred that the second hypothesis (H2) is rejected, implying that institutional ownership does not affect earnings quality. It may be due to a lack of management performance control, resulting in less-than-optimal management performance outcomes. Dewi (2019) reports that business governance can be affected by institutional ownership, which, according to the theory of aggression, would promote better supervision. Furthermore, institutional ownership focuses on the market response by rising share prices to not link institutional ownership to earnings quality (Listianingsing, 2020). Fundamentally, corporate ownership will encourage management to improve corporate performance by increasing profit from the company's operations. This research, however, shows that institutional ownership has little impact on income quality, which means that institutional investors are not dependent on current earnings. Institutional investors are more focused on long-term business success, so institutional ownership of shares may be an obstacle to opportunistic behavior managers (Irawati and Sudirman, 2016).

Furthermore, managers seek to manipulate income to achieve institutional shareholders' profit targets. Management continues to conduct earnings management to satisfy its large institutional shareholders (Ujiyantho and Pramuka, 2007). It reduces the quality of earnings and makes it impossible to explain the actual income or profits produced by the company's operations (Nanang \& Tanusdjaja, 2019). This study's findings support the findings of (Nuryana \& Surjandari, 2019), who claim that institutional ownership has no impact on earnings management. Unlike previous studies (Barkadehi and Mirbargkar, 2017; Mehrani et al., 2017), institutional ownership impacts earnings quality.

In this analysis, the regression results from the t-test between the independent board of commissioners on earnings efficiency indicated a significant p-value of 0.2841 , which is greater than $a=0.05$. The third hypothesis $(\mathrm{H} 3)$ is thus dismissed, implying that the independent board of commissioners has little effect on quality earnings. It is because the company's independent board of commissioners is unable to fulfil its responsibilities. Table 2 on Descriptive statistics shows that the average value of the independent board of commissioners of mining companies listed on the Indonesian stock exchange for the period 2014-2018 is very low at 38.73\% below 50\%. It indicates that independent commissioners have little operational control of the company because of the company's small number of independent commissioners. Failure to control will result in company fraud resulting in reduced income for the company, which does not correspond with the current situation (Nanang \& Tanusdjaja, 2019). Centralized ownership of the shares of a single group or family may be one of the reasons for the weakness of the independent board of commissioners, since the appointment of an independent commissioner is provided as a mere sense of appreciation or based on family relations or close ties, notwithstanding the integrity, capacity and independence of the commissioner, which is essential to quality earnings (Effendi 2009). The findings of this study are consistent with previous studies (Nuryana \& Surjandari, 2019; Nanang \& Tanusdjaja, 2019) that the independent board of commissioners has no impact on the quality of earnings. In 
comparison to previous studies' findings, Arniati et al. (2019) reported that an independent board of commissioners could improve the quality of earnings.

The regression results on the t-test in this analysis suggest that the audit committee's impact on earnings efficiency shows a significant $p$-value of 0.0164 lower than $a=0.05$. As a result, we can assume that the fourth hypothesis $(\mathrm{H} 4)$ is accepted. It implies that the audit committee has a direct influence on the quality of the earnings. It demonstrates that the greater the number of audit committees, the higher the quality of earnings. The audit committee's effect on the quality of earnings is attributed to the fact that the audit committee, composed of independent parties, has excellent knowledge of finance and accounting. Besides, the audit committee does an excellent job of monitoring external reporting systems, adhering to regulations, and ensuring formal communication with the board of directors, management, external auditors, and internal auditors. These study findings are consistent with previous research (Hamdan, 2020; Mahdi Obaid \& Rajab Amrah, 2020), which states that the audit committee substantially influences earnings quality. In comparison to the findings of Handoko \& Horison (2020), Nuryana \& Surjandari (2019), Nanang \& Tanusdjaja (2019), the audit committee does not affect the quality of earnings due to the limited authority of the audit committee to carry out its duties.

Regression findings in this analysis show that CSR disclosure of earnings quality on the t-test shows a significant $\mathrm{p}$-value of 0.2703 , which is greater than $a=$ 0.05. The fifth hypothesis (H5) can be concluded to be rejected. It ensures that the disclosure of CSR does not affect the quality of earnings. Due to managerial opportunism, managers use CSR practices as opportunistic incentives to hide company wrongdoings. CSR disclosure will intensify agency issues and trigger profit-seeking insiders to conceal the company's actual performance (Jouber, 2019). according to Theory Agency (Jensen \& Meckling, 1976), The managerial opportunism hypothesis predicts a negative relationship between CSR disclosure and Earning Quality. This study's findings are consistent with previous studies by Hutasoit et al. (2020), which reports that CSR disclosure has no impact on earnings quality. However, this differs from previous research (Park \& Ha, 2020; Rezaee et al., 2019; Jouber, 2019: Bagus \& Djaddang, 2018), which claims that CSR disclosure has a positive impact on earnings quality. The more companies perform CSR, the greater the confidence of market participants in the information on earnings.

The t-test results in this analysis show that the quality of earnings on stock returns has a p-value significance of 0.0094 , which is smaller than the significance of $\alpha=0.05$, indicating that the sixth hypothesis (H6) is accepted. Quality profit can be perceived as having a significant positive impact on stock returns. This study's findings show that earnings quality is a factor that influences stock returns and that earnings information is a positive signal for investors (Yuliza, 2018). The study results correlate to previous research (Simorangkir, 2019; Yuliza, 2018; Damanik et al., 2019), which shows that the quality of earnings significantly has a positive impact on the returns on the stock. Nurmasari (2018), on the other hand, claims that earnings efficiency does not affect stock returns, contrary to previous studies. 


\section{CONCLUSIONS AND SUGGESTIONS}

\section{Conclusions}

Based on the research results by performing two regressions, the audit committee will improve company earnings quality in the first regression. The audit committee, which is part of the GCG mechanism, consists of independent parties with adequate financial and accounting expertise to increase earnings quality. The involvement of this independent audit committee is a signal of the integrity of the good earning quality of the company. However, the GCG system has not improved the quality of financial results, especially earnings quality, through managerial ownership, institutional ownership and the independent committee of commissioners.

The second regression indicates that the quality of earnings leads to shareholders' investment because good earnings quality increases high returns on investment. The facts of the company's performance reflected in the earnings quality information so that investors respond positively, which is reflected in their investment decision-making.

\section{Suggestions}

For future studies, the research object should be extended to include companies from other sectors to be compared to previous results. The findings of this study will be helpful in further research into the GCG mechanism in Indonesia. As a result, future research will continue to be very important. Future research should test and re-examine the GCG process using a set of variables relevant to the consistency of a company's earnings.

Investors should be more selective in their future investments in the business. To make the best decision, investors must pay careful attention to the company's financial details. Since stable company earnings do not guarantee current performance conditions, reading the company's financial statements in their entirety includes the income statement and reviewing the company's past financial statements to determine the company's overall growth and condition.

Based on this report's findings, the organization should devote more resources to internal control functions such as supervision and monitoring by the audit committee as a GCG mechanism to enhance company performance. Furthermore, the company is required to include as much financial information as possible that explains the actual details of the company's performance in order for investors to react favorably, resulting in higher share prices.

In the meantime, for knowledge development, this is the starting point for an analysis of the company's financial efficiency, which is greatly aided by the implementation of a suitable GCG mechanism. As a result, a thorough investigation into the GCG mechanism and CSR disclosure role in promoting earnings quality and providing accurate company performance data is needed. 


\section{LIMITATIONS}

In this mining sector study, the CSR disclosure variable is focused solely on subjective assessments so that the evaluation of the results can differ. Future studies should be planned to evaluate the CSR index using Sustainability Reporting, which the Global Reporting Initiative has cross-checked. This attempts to avoid subjective judgments to justify the evaluation outcomes.

\section{REFERENCES}

Arisanti, I. (2020). Analysis on Earnings Persistence, Independent Commissioner and Herding Behavior on Eraning Quality. Journal of Accounting and Business Education, 5(September), 38-53. https:/ / dx.doi.org.10.26675/jabe.v3i2.6846

Arniati, T., Puspita, D. A., Amin, A., \& Pirzada, K. (2019). The Implementation of Good Corporate Governance Model and Auditor Independence in Earnings' Quality Improvement. Entrepreneurship and Sustainability Issues,7(1)188-200. https:// doi.org/10.9770/jesi.2019.7.1(15)

Bagus, R., \& Djaddang, S. (2018). Valuasi kesadaran lingkungan , Corporate Social Responsibility Terhadap Kualitas Laba dengan Moderasi Komite Audit. Jurnal Ekonomi Dan Bisnis, 21(1), 97-114. https:/ / doi.org/10.24914/jeb.v21i1.1042

Ball, R. J. and Brown, P. (1968). 'An Empirical Evaluation of Accounting Income Numbers', Journal of Accounting Research, 6 (Autumn), pp. 159-178. https:// doi.org/10.2307/2490232

Barkadehi, H. K., \& Mirbargkar, S. M. (2017). The Role of Ownership in the Earning Quality: Evidence from Listed Firms of Tehran Stock Exchange. International Journal of Economic Perspective, 11(1), 1109-1118. https:// doi.org/10.5267/j.msl.2013.03.017

Beaver, W. H. (1968). 'The Information Content of Annual Earnings Announcements', Empirical Research in Accounting: Selected Studies, Supplement Vol. 6 of Journal of Accounting Research, pp. 67-92. https:/ / doi.org/10.2307/2490070

Bushee, Brian J., 1998. The Influence of Institutional Investors on Myopic R\&D Investment Behavior. The Accounting Review Vol. 73, No. 3, pp. 305-333.

Brailsford, T. J., Oliver, B. R., \& Pua, S. L. H. (2002). On the Relation Between Ownership Structure and Capital Structure. Accounting and Finance, 42(1), 1-26. https:// doi.org/10.1111/1467-629X.00001

Brigham, E. dan J. F. H. (2019). Dasar-Dasar Manajemen Keuangan. Buku 1. Edisi 14. Penerjemah Ali Akbar Yulianto. Jakarta. Salemba Empat.

Connelly, B. L., Certo, S. T., Ireland, R. D., \& Reutzel, C. R. (2011). Signaling theory: A review and assessment. Journal of Management, 37(1), 39-67. https:// doi.org/10.1177/0149206310388419

Damanik, P. J., Pancasila, U., Akuntansi, M., \& Pancasila, U. (2019). Kemampuan Net Income, Other Comprehensive Income, Return dan Peran Pemoderasi Kualitas Laba. Jurnal Riset Akuntansi Dan Perpajakan, 6(1), 63-74. 
Dechow, P., Ge, W., \& Schrand, C. (2010). Understanding earnings quality: A review of the proxies, their determinants and their consequences. Journal of Accounting and Economics, 50(2-3), 344-401. https:// doi.org/10.1016/j.jacceco.2010.09.001

Effendi, Arief.(2009). The Powerrof Goodd Corporate Governance Teoriidan Implementasi. Jakarta: Salemba Empat.

Eugene F. brigham, J. F. H. (n.d.). Fundamentals of Financial Management (15th Edition) eBook. Cengage Learning.

Febriani, K., Saraswati, D., Merawati, L. K., \& Munidewi, I. A. B. (2020). Pengaruh Likuiditas, Leverage, dan Good Corporate. Jurnal Ekonomi dan Pariwisata 15(2), 79-89. https://doi.org/10.37403/ financial.v3i2.51

Global Reporting Initiative (GRIa). 2013. Pedoman Laporan Berkelanjutan G4. Amsterdam

Global Reporting Initiative (GRIb). 2013. GRI Sustainability Reporting Process. Amsterdam

Hapsari, Indri and Imam Ghozali (2011). Hubungan antara GCG, Transparansi dan Kinerja Perusahaan. Undergraduate thesis (unpublished), Universitas Diponegoro

Hamdan, A. (2020). The Role of The Audit Committee in Improving Earnings Quality: The Case of Industrial Companies in GCC. Journal of International Studies, 13(2), 127-138. https:/ / doi.org/10.14254/2071-8330.2020/13-2/9

Handoko, B. L., \& Arbi, D. Y. (2020). How Corporate Governance Able to Moderate Income Smoothing in Mining Sector. International Journal of Management, 11(5), 486-496.

Handoko, B. L., \& Horison, R. (2020). The Effect of Firm Size, Audit Committee, Leverage and Institutional Ownership on Earnings Quality. International Journal of Recent Technology and Engineering, 8(5), 4510-4516.

Hapsoro, D., \& Shufia, A. M. (2018). Does Managerial Ownership Moderate the Effect of Managerial Ability on Earnings Quality? A comparative Study of Manufacturing Companies in Indonesia and Malaysia. The Journal of Social Sciences Research, (SPI 2), 639-647. https://doi.org/10.32861/jssr.spi1.639.647

Hartono, J. (2017). Teori Portofolio dan Analisis Investasi, Edisi 11. Yogyakarta: BPFE.

Hutasoit, S., Harahap, K., Nst, A. H., Teori, L., \& Pengembangan, D. (2020). Pengaruh Corporate Social Responsibility Terhadap Earning Quality Pada Perusahaan Pertambangan Yang Terdaftar Di Bursa Efek Indonesia Tahun 2015 - 2017. Jurnal Akuntansi, Keuangan Dan Perpajakan Indonesia (JAKPI), 0-10.

Indonesia, I. A., \& IAI. (2015). Modul Chartered Accountant - Pelaporan Korporat. Ikatan Akuntan Indonesia.

Irawati dan Sudirman. (2016). Pengaruh Good Corporate Governance terhadap Kualitas Laba pada Perusahaan Food and Beverages yang Listing di Bursa Efek Indonesia Periode 2013-2015 
Ismail. (2018). Pengaruh Prinsip Konservatisme Akuntansi Terhadap Mekanisme Good Corporate Governance dan Kualitas Laba Perusahaan. Bongaya Journal for Research in Accounting, 1(1), 1-7. https://doi.org/10.37888/bjra.v1i1.28

James Ohlson. (1995). Earnings, book-values, and dividends in equity valuation. Contemporary Accounting Research, 11(11), 661-687. https://doi.org/10.1111/j.1911-3846.1995.tb00461.x

Jensen, M., \& Meckling, W. H. (1976). Theory of the firm: Managerial behavior, agency costs and ownership structure. Journal of Financial Economics, 3(4), 305-360. https:/ / doi.org.10.1016/0304-405X(76)90026-X

Jouber, H. (2019). Corporate social responsibility and earnings quality: do institutional features matter? Journal of Global Responsibility, 11(1), 54-92. https:/ / doi.org/10.1108/JGR-04-2019-0041

Listyaningsih, \& Fransisca. (2020). Investment Opportunity Set and Good Corporate Governance to Earnings quality. EPRA International Journal of Multidisciplinary Research (IJMR)-Peer Reviewed Journal, (2), 242-251. https:// doi.org/10.36713/epra3955

Mahdi Obaid, M., \& Rajab Amrah, M. (2020). Emerging policies and the effectiveness of corporate governance mechanisms on earning quality: A conceptual framework for Gulf cooperation council. Internasional Journal of Research Business and Social Science (IJRBS), 9(3), 157-164. https:/ / doi.org/10.20525/ijrbs.v9i3.691

Mehdi, M., Sahut, J.-M., \& Teulon, F. (2017). Do corporate governance and ownership structure impact dividend policy in emerging market during financial crisis? Journal of Applied Accounting Research, 18(3), 274-297. https:/ / doi.org/10.1108/JAAR-07-2014-0079

Mehrani, S., Moradi, M., \& Eskandar, H. (2017). Institutional Ownership Type and Earnings Quality: Evidence from Iran. Journal of Emerging Markets Finance and Trade, 53(1), 54-73. https:/ / doi.org/10.1080/1540496X.2016.1145114

Mukhtaruddin, Ferina, I. S., \& Nurcahaya, C. (2014). Ownership Structure and Firm Values: Empirical Study on Indonesia Manufacturing Listed Companies. Journal of Arts, Science \& Commerce, V (4), 1-14.

Muttakin, M. B., Khan, A., \& Azim, M. I. (2015). Corporate social responsibility disclosures and earnings quality: Are they a reflection of managers' opportunistic behavior? Managerial Auditing Journal, 30(3), 277-298. https:/ / doi.org/10.1108/MAJ-02-2014-0997

Nanang, A. P., \& Tanusdjaja, H. (2019). Pengaruh Corporate Governanve (CG) Terhadap Kualitas Laba dengan Manajemen Laba Sebagai Variabel Intervening pada Perusahaan Manufaktur. Jurnal Muara Ilmu Ekonomi Dan Bisnis, 3(2), 267-288. https://10.24912/jmieb.v3i2.2909

Nasrum, M. (2018). Corporate Governance (Konsep, Teori dan Aplikasi di Beberapa Negara Asia).

Nurmasari, I. (2018). Pengaruh Rasio Keuangan Dan Pertumbuhan Pendapatan Terhadap Return Saham Pada Perusahaan Perkebunan Di Bursa Efek Indonesia 2010-2017. 
Jurnal SEKURITAS (Saham, Ekonomi, Keuangan Dan Investasi), 2(1). https://dx.doi.org/10.32493/skt.v2i1.1959

Nuryana, Y., \& Surjandari, D. A. (2019). The Effect of Goood Corporate Governance Mechanism, and Earning Management on Company Financial Performance. Global Journal of Management and Businessn Research, 19(1), 26-39.

Park, H. J., \& Ha, M. H. (2020). Corporate Social Responsibility and Earnings Transparency: Evidence from Korea. Corporate Social Responsibility and Environmental Management, 27(3), 1498-1508. https:// doi.org/10.1002/csr.1992

Polimpung, L. J. C. (2020). Pengaruh Good Corporate Governance Terhadap Kualitas Laba Perusahaan (Studi pada Perusahaan Sektor Consumer Goods dalam Bursa Efek Indonesia Periode 2016-2018). Jurnal Akuntansi, 12(2), https:// doi.org/10.28932/jam.v12i2.2305

Putra, R. A. K. (2020). Analisis Ukuran Perusahaan Dan Peluang Investasi Di Masa Depan. Jurnal Ekonomi Dan Bisnis, 7(2), 117-125. https:// doi.org/10.34308/eqien.v7i2.148

Ray, B., \& Philip, B. (1968). Empirical evaluation of accounting income numbers. Journal of Accounting Research, Vol 6(1929), p 159-178. https:/ / doi.org/10.2307/2490232

Rezaee, Z., Dou, H., \& Zhang, H. (2019). Corporate social responsibility and earnings quality: Evidence from China. Global Finance Journal, (April), 100473. https:// doi.org/10.1016/j.gfj.2019.05.002

Safitri, R., \& Mayar, A. (2020). Pengaruh ukuran perusahaan, siklus operasi, dan konservatisme akuntansi terhadap kualitas laba.Jurnal Eksplorasi Akuntansi 2(4), Seri E, 3793-3807. https://doi.org/10.24036/jea.v2i4.319

Sahla, A., Widya \& Aliyah, Siti Sopiah Rothbatul. (2016). Pengungkapan Corporate Social Responsibility berdasarkan Global Reporting Initiative pada Perbankan Indonesia. Jurnal INTEKNA, Volume 16, No. 2 (Nopember)

Setiyawati, H., \& Basar, Y. S. (2017). Pengaruh Pengungkapan Corporate Social Responsibility dan Penerapan Good Corporate Governance Terhadap Tingkat Profitabilitas (Studi Empiris Pada Perusahaan Sektor Pertambangan Yang Terdaftar Di BEI). Jurnal Akuntansi, 21(3), 351. https://dx.doi.org/10.24912/ja.v21i3.266

Siallagan, H., \& Machfoedz, M. (2006). "Mekanisme Good Corporate Governance, Kualitas Laba dan Nilai Perusahaan". Simposium Nasional Akuntansi IX Padang.

Simorangkir, R. T. M. C. (2019). Pengaruh Kinerja Keuangan Terhadap Return Saham Perusahaan Pertambangan. Jurnal Bisnis Dan Akuntansi, 21(2), 155-164. https:// doi.org/10.34208/jba.v21i2.616

Sulistyanto, \& Sri, H. (2014). Manajemen Laba: Teori dan Model Empiris. Jakarta: Grasindo.

Surjandari, D. A., \& Wati, L. N. (2020). Dividend Policy, Economic Value Added, Market $\beta$, Firm Size and Stock Return. Accounting and Finance Research, 9(3), 53. https:// doi.org/10.5430/afr.v9n3p53 
Suwarno, S., Rahmawati, R., Djuminah, D., \& Muthmainah, M. (2020). Is Corporate Social Responsibility Disclosure Good for Accrual Profit and Real Manipulative Profit Managements? Journal of Southwest Jiaotong University, 55(2). https:// doi.org/10.35741/issn.0258-2724.55.2.53

Ujiyantho dan Pramuka. (2007). Mekanisme Corporate Governance, Manajemen Laba dan Kiinerja Keuangan. Prosiding, Simposium Nasional Akuntansi X, Makassar.

Wahyudi, W., Setiany, E., \& Utami, W. (2020). The good corporate governance mechanism and earnings management: Evidence from Indonesian and Malaysian manufacturing companies. Public Sector Accountants and Quantum Leap: How Far We Can Survive in Industrial Revolution 4.0? pp. 89-94. https:// doi.org/10.1201/9780367822965

Walsh, J. P., \& Seward, J. K. (1990). On the Efficiency of Internal and External Corporate Control Mechanisms. Academy of Management Review, 15(3), 421-458. https:// doi.org/10.5465/amr.1990.4308826

Warianto, P., \& Rusiti, C. (2014). Pengaruh Ukuran Perusahaan, Struktur Modal, Likuiditas Dan Investment Opportunity Set (Ios) Terhadap Kualitas Laba Pada Perusahaan Manufaktur Yang Terdaftar Di Bei. Modus Jurnal Ekonomi Dan Bisnis, 26(1), 19. https://doi.org/10.24002/modus.v26i1.575

Watts, Ross L: Zimmerman, J. L. (1986). Positive Accounting Theory, Prentice Hall, Inc. Chapter 1, 2, 14, dan 15.

Yuliza, A. (2018). The Effects of Earnings Per Share and Firm Size to Stock Price LQ45 Company Listed in Indonesian Securities. International Journal of Engineering \& Technology,7(4.9),24. https:/ / doi.org/10.14419/ijet.v7i4.9.21089 